\title{
The Correlation of Discrimination and Violence with Life Satisfaction, Happiness and Personal Well-being among Persons with Physical and Sensory Disabilites
}

\author{
Marko Marinić* \\ marko.marinic@pilar.hr \\ https://orcid.org/0000-0002-9683-7571
}

https://doi.org/10.31192/np.18.3.9

UDK / UDC: 316.647.82-056.26/.3

$17.023 .34-056.26 / .3$

Original scientific paper / Izvorni znanstveni rad

Primljeno / Received: 9. srpnja 2020. / Jul 9, 2020

Prihvaćeno / Accepted: 21. rujna 2020. / Sep 21, 2020

The aim of this paper is to explore the frequency of experiences of discrimination and violence among persons with various types of disabilities, investigate the correlation of these topics with particular sociodemographic characteristics and with the level of happiness and life satisfaction, and identify which one of the various personal well-being domains is particularly connected with discrimination and violence. The empirical study was conducted among 684 persons with various types of disabilities in the city of Zagreb, Croatia. The results indicate a high percentage of experienced discrimination and violence in all groups of respondents, especially the deaf and those hard of hearing. Both topics are negatively correlated with the level of personal happiness, life satisfaction and all domains of personal well-being. It was found that the frequency of these experiences is related to younger age, and to lower income and poor economic status. The results point to the need for a multi-disciplinary and comprehensive engagement on reducing discrimination and violence over persons with disabilities.

Key words: Discrimination, Happiness, Personal well-being, Persons with disabilities, Violence.

\footnotetext{
* Marko Marinić, PhD, Senior Research Associate at Institute of Social Sciences »Ivo Pilar«; Address: Marulićev trg 19, HR-10000 Zagreb, Croatia.
} 


\section{Introduction}

The topic of discrimination and violence among various social groups is found in a number of scientific and professional analyses. ${ }^{1}$ The same could be said for the research into quality of life, personal well-being and level of life happiness. ${ }^{2}$ However, in both cases the level of knowledge is far from satisfactory. This particularly refers to the level of knowledge in the context of minority groups, such as persons with disabilities, not to mention the interrelations of these topics in such population.

\section{Discrimination and Violence among Persons with Disabilities}

From the aspect of official documents, The UN Convention on the Rights of Persons with Disabilities defines discrimination on the basis of disability as any distinction, exclusion or restriction on the basis of disability which has the purpose or effect of impairing or nullifying the recognition, enjoyment or exercise, on an equal basis with others, of all human rights and fundamental freedoms in the political, economic, social, cultural, civil or any other field. ${ }^{3}$ At the same time, World Health Organization defines violence as deliberate use of physical force or power, by threat or realization, against oneself, other person, group or community, and resulting or being highly likely to result with injury, death, psychological wounds, hindered development or deprivation. ${ }^{4}$

Numerous global studies, official states' acts and civil society organizations' activities show that both discrimination and violence are very much present among persons with disabilities, in various ways and on various bases. Austra-

\footnotetext{
${ }^{1}$ Eg. S. GRBIĆ, D. BODUL, V. SMOKVINA (2012). Diskriminacija osoba s invaliditetom i njihova uključenost u društvo s naglaskom na pravo pristupa sudu, Zbornik Pravnog fakulteta Sveučilišta u Rijeci, 33 (2012) 2, 667-693; S. RUSAC, A. ŠTAMBUK, J. VERIĆ, Dobna diskriminacija: iskustva starijih osoba, Hrvatska revija za rehabilitacijska istraživanja, 49 (2013) 96-105 (Supplement).

${ }^{2}$ For more on these concepts see: M. TADIĆ, Što mjerimo kada mjerimo sreću? Metodološki izazovi istraživanja sreće, Društvena istraživanja, 112 (2011) 2, 317-336; LJ. KALITERNALIPOVČAN, A. BRAJŠA-ŽGANEC, Kvaliteta življenja, sreća i životno zadovoljstvo u Hrvatskoj i zemljama EU, te usporedbe sjeverozapadne i ostalih dijelova Hrvatske, Radovi Zavoda za znanstveni rad Varaždin, 28 (2017) 139-153; I. KOVČO VUKADIN, M. NOVAK, H. KRIŽAN, Zadovoljstvo životom: individualna i obiteljska perspektiva, Kriminologija E socijalna integracija, 24 (2016) 1, 84-115.

3 Croatian Parliament, Zakon o potvrđivanju Konvencije o pravima osoba s invaliditetom i Fakultativnog protokola uz Konvenciju o pravima osoba s invaliditetom, Narodne novine, 6 (2007); https://narodne-novine.nn.hr/clanci/medunarodni/2007_06_6_80.html (12 Apr. 2020).

${ }^{4}$ E. G. KRUG et al. (Eds), World Report on Violence and Health, Geneva, World Health Organization, 2002, 5.
} 
lian Human Rights Commission ${ }^{5}$ finds that disability discrimination is when a person with disability is treated less favourably than a person without disability in the same or similar circumstances, which happens in various spheres of life - employment, education, accommodation, getting or using services and accessing public places. The authors Poredoš at al. ${ }^{6}$ point out that persons with disabilities experience the same kinds of violence as persons without disabilities, but they can be subject to numerous other kinds of violence, related to the fact of their disability. These are additional types of control or restraining from appropriate action (for example, refusing to provide medicine or medical aids), deliberate setting up of obstacles that hinder movement of persons with disabilities, calling them names and making fun of them, excluding from communication, bringing to social isolation, etc.

Analysing risk factors of violence over persons with disabilities through findings of various studies, the author Milić Babić ${ }^{7}$ finds a plethora of them. Some of them are increased dependency on long-term care from others; deprivation of human rights resulting in perceived inability; lower risk of being discovered perceived by perpetrators of violence; the hardship the victims of violence face in proving; social isolation and increased risk of manipulation; physical inability and vulnerability in public places; lack of information; lower level of education; economic dependency of the victim, etc.

The differences between persons having particular types of disabilities were also found, however, interesting is also the finding that most of these studies are focused on persons with mental illnesses, while other types of disabilities are quite neglected. ${ }^{8}$ The lack of knowledge on the specificities of violence among persons having specific types of disabilities can be further contributed to clearly by the fact that violence over persons with disabilities is sometimes very hard to identify and it remains unrecognized. Even professionals dealing with persons with disabilities have problems with recognizing this phenomenon, and sometimes they are not enough sensibilized and educated for providing adequate help and support to victims with disabilities. ${ }^{9}$ It is unsurprising

${ }^{5}$ Australian Human Rights Commission, Know your Rights: Disability Discrimination (2012), https://www.humanrights.gov.au/our-work/disability-rights/know-your-rights-disability-discrimination (3 May 2020).

${ }^{6}$ D. POREDOŠ LAVOR, M. BOSNIĆ, Nasilje nad slijepim i slabovidnim osobama, Policija $i$ sigurnost, 22 (2013) 4, 471-478, 473.

7 M. MILIĆ BABIĆ, Nasilje i osobe s invaliditetom, Ljetopis socijalnog rada, 16 (2009) 3, 595614,603 s.

${ }^{8}$ K. HUGHES et al., Prevalence and Risk of Violence Against Adults with Disabilities: A Systematic Review and Meta-analysis of Observational Studies, The Lancet, 379 (2012) 9826, 1621 $1629,1626$.

${ }^{9}$ K. ŠESTO, M. BULJEVAC, Z. LEUTAR, Iskustva stručnjaka o nasilju nad osobama s invaliditetom, Socijalna psihijatrija, 43 (2015) 2, 59-66, 59. 
that in some persons with disabilities there are passive strategies of coping still present - such as withholding, avoidance or retreat. ${ }^{10}$

Inadequate coping strategies are indeed one of the causes why studies such as Dembo at al. ${ }^{11}$ clearly detect high risk of psychological consequences related to violence victimization, and suggest that people with disabilities are particularly vulnerable to adverse psychological outcomes.

\section{Personal Happiness and Life Satisfaction among Persons with Disabilities}

The research that have investigated adaptation of persons with more severe disabilities do not always yield unambiguous results. Allman ${ }^{12}$ finds persons confined to lifetime use of a wheelchair to be equally happy as the control group of healthy individuals, while another study points to lower life satisfaction and incomplete adaptation of persons with disabilities, especially those with multiple disfunctions..$^{13}$

Weinberg ${ }^{14}$ argues that persons successfully dealing with disability are satisfied if they managed to achieve their goals, no matter the disability, or even because of it, and despite the tendencies of society to view disability as continuous tragedy.

The social environment, i.e. the quality of social relations of a disabled person and their environment is largely related to the level of happiness and personal well-being of the disabled. For example, the community in which a person with disability is accepted and where members of the community are supportive will surely contribute to the person with disability evaluating the quality of life as better, than in the case of living in a community where the person with disability feels different and less worthy. ${ }^{15}$ The study by Marinić

\footnotetext{
${ }^{10}$ M. BULJEVAC, M. GREGURIĆ, M. MILIĆ BABIĆ, Strategije suočavanja s nasiljem i percipirani oblici podrške iz perspektive osoba s invaliditetom, in: M. ŽITNIK et al. (Eds.) Zbornik sažetaka. M eđunarodna znanstvena konferencija »Socijalni rad $i$ borba protiv siromaštva i socijalne isključenosti - profesionalna usmjerenost zaštiti i promicanju ljudskih prava«, Mostar, Filozofski fakultet Sveučilišta u Mostaru, Zaklada Marija de Mattias u Zagrebu, 2010, 71.

${ }^{11}$ R. S. DEMBO, M. MITRA, M. MCKEE, The Psychological Consequences of Violence Against People with Disabilities, Disability and Health Journal, 11 (2018) 3, 390-397.

${ }^{12}$ A. ALLMAN, Subjective Well-Being of People with Disabilities: Measurement Issues, Chicago, University of Illinois, 1990.

${ }^{13}$ T. MEHNERT et al., Correlates of Life Satisfaction in Those with Disabling Conditions, Rehabilitation Psychology, 35 (1990) 3-17.

${ }^{14}$ N. WEINBERG, Another Perspective: Attitudes of People with Disabilities, in: H. E. YUKER (Ed.), Attitudes Toward Persons with disabilities, New York, Springer, 1988, 141-153.

${ }^{15}$ Z. LEUTAR, M. BULJEVAC, Osobe s invaliditetom u društvu, Zagreb, Pravni fakultet, 2020, 142.
} 
and Brkljačić16 also clearly showed that the quality of social relations is an exceptionally important predictor of happiness among persons with disabilities.

Diener et al. ${ }^{17}$ ascertain that happiness does not correlate with objective (medical) assessments of health status, but with subjective ones. Thus, persons feeling healthier will be happier, which does not necessarily reflect the actual health status.

Along with those lines are findings of particular studies pointing out that sometimes persons with severe disabilities report high or exceptionally high quality of life, which Sol Levine named the "disability paradox " phenomenon. ${ }^{18}$ Analysing this phenomenon in their study, Albrecht and Devliger infer that the disability paradox really exists. A part of persons with disabilities included in this survey emphasize that the experience of disability was the one that clarified the meaning of life to them and changed their value system. These participants have altered the standards by which they evaluate success, and the quality of their life arises from successful functioning with the shape of the organism with which they live in reality. Still, this phenomenon is less likely to occur in the cases of disability that produces fatigue, constant or unpredictable pain and in physical and social environments that discourage from becoming empowered and acting as agent in one's own life. Low quality of life of persons with disabilities is based on dificult-to-manage impairments, lack of knowledge and resources and disabling environments. ${ }^{19}$

\section{Aims of the Study}

This study aims to ascertain the kind of interplay that exists between discrimination and violence in relation to happiness, as an affective component of subjective well-being, and life satisfaction, as a cognitive component of subjective well-being, among persons with disabilities. The starting point of this attempt is the notion that discrimination and violence are widespread in the population of persons with disabilities, and that both misconducts are done to them by members of their social environment, which can have numerous psychophysical consequences for persons with disabilities. However, persons with disabilities can sometimes express a high level of life satisfaction, despite their

\footnotetext{
${ }^{16}$ M. MARINIĆ, T. BRKLJAČIĆ, Love Over Gold. The Correlation of Happiness Level with Some Life Satisfaction Factors Between Persons with and Without Physical Disability, Journal of Developmental and Physical Disabilities, 20 (2008) 6, 527-540, 536.

${ }^{17}$ E. DIENER, R. LUCAS, Personality and Subjective Well-Being, in E. KAHNEMAN, E. DIENER, N. SCHWARTZ (Eds.) Well Being: The Foundations of Hedonic Psychology, New York, Russell Sage Foundation, 1999, 213-229.

${ }^{18}$ G. L. ALBRECHT, P. J. DEVLIEGER, The Disability Paradox: High Quality of Life Against all Odds, Social Science \& Medicine, 48 (1999) 977-988, 977s.

${ }^{19} \mathrm{Ibid}, 986$.
} 
health status. We therefore set the following aims of the study - to explore the frequency of experiences of discrimination and violence among persons with disabilities and ascertain if there are any differences with regard to the type of disability; to investigate the correlation of some sociodemographic characteristics with the experience of discrimination and violence; to examine the correlation of discrimination and violence with the level of happiness and life satisfaction of persons with disabilities, and to identify which of the various personal well-being domains are discrimination and violence most connected with.

\section{Method}

\subsection{Procedure and Sample}

The empirical study was carried out in 2015/2016 among persons with disabilities in Zagreb, Croatia. They were recruited via several civil society organizations of persons with disabilities, which gather their membership according to the type of disability. Two research approaches were used - the method of postal survey (the questionnaire was sent to home addresses together with stamped and addressed envelopes) and the method of direct surveying for a part of respondents in the group of deaf/hard of hearing and blind/partially sighted persons, who were unable to read and fill-in the questionnaires on their own. At the beginning of the questionnaire, the purpose of the survey was explained, the instructions for filling-in the questionnaire were provided, and the motivational letter was enclosed.

By employing the method of systematic probabilistic sampling we involved members of several civil society organizations of persons with disabilities in the city of Zagreb in the survey, and the sample was stratified proportionally to the size of CSOs.

Out of a total of 1,630 of distributed questionnaires, 684 or $42 \%$ of them were returned. Due to the specificities of particular types of disability, and for the transparency of comparisons and table view of the results, the sample was first divided into persons with physical and persons with sensory disabilities. Afterwards, the sub-sample of persons with physical disabilities was divided into those who move more easily (those who can walk alone or with the help of a medical aid or another person) and those who move with difficulty (those who can move in a wheelchair or are completely immovable); while the subsample of persons with sensory disabilities was divided into the deaf and blind. The structure of the achieved sample divided as explained is displayed in Table I. 
Table I. Achieved sample according to types of disabilities

\begin{tabular}{|c|c|c|c|c|c|c|}
\hline & & \multicolumn{2}{|c|}{ Physical disability } & \multicolumn{2}{|c|}{ Sensory disability } & \multirow[b]{2}{*}{ Total } \\
\hline & & $\begin{array}{c}\text { Easier } \\
\text { movable }\end{array}$ & $\begin{array}{c}\text { Hard of } \\
\text { moving or } \\
\text { immovable }\end{array}$ & $\begin{array}{l}\text { Deaf and } \\
\text { hard of } \\
\text { hearing }\end{array}$ & $\begin{array}{c}\text { Blind } \\
\text { and } \\
\text { partially } \\
\text { sighted }\end{array}$ & \\
\hline \multirow{2}{*}{$\begin{array}{l}\text { Zagreb Muscular Dystrophy } \\
\text { Society }\end{array}$} & $\mathrm{N}$ & 43 & 49 & 0 & 0 & 92 \\
\hline & $\%$ & 46.74 & 53.26 & 0 & 0 & \\
\hline \multirow{2}{*}{$\begin{array}{l}\text { Association of persons with } \\
\text { cerebral palsy and polio Zagreb }\end{array}$} & $\mathrm{N}$ & 44 & 45 & 0 & 0 & 89 \\
\hline & $\%$ & 49.44 & 50.56 & 0 & 0 & \\
\hline \multirow{2}{*}{$\begin{array}{l}\text { Multiple Sclerosis Society of } \\
\text { Zagreb }\end{array}$} & $\mathrm{N}$ & 95 & 34 & 0 & 0 & 129 \\
\hline & $\%$ & 73.64 & 26.36 & 0 & 0 & \\
\hline \multirow{2}{*}{$\begin{array}{l}\text { Zagreb Association of the } \\
\text { Physically Disabled }\end{array}$} & $\mathrm{N}$ & 85 & 27 & 0 & 0 & 112 \\
\hline & $\%$ & 75.89 & 24.11 & 0 & 0 & \\
\hline \multirow{2}{*}{$\begin{array}{l}\text { Association of the Deaf and } \\
\text { Hard of Hearing of the City of } \\
\text { Zagreb }\end{array}$} & $\mathrm{N}$ & 0 & 0 & 103 & 0 & 103 \\
\hline & $\%$ & 0 & 0 & 100 & 0 & \\
\hline \multirow{2}{*}{ Spinal Injuries Zagreb } & $\mathrm{N}$ & 6 & 44 & 0 & 0 & 50 \\
\hline & $\%$ & 12 & 88 & 0 & 0 & \\
\hline \multirow{2}{*}{$\begin{array}{l}\text { Zagreb Association of Blind } \\
\text { Persons }\end{array}$} & $\mathrm{N}$ & 0 & 0 & 0 & 109 & 109 \\
\hline & $\%$ & 0 & 0 & 0 & 100 & \\
\hline Total & $\mathrm{N}$ & 273 & 199 & 103 & 109 & 684 \\
\hline
\end{tabular}

Slightly more female (56.4\%) than male (43.86\%) respondents participated in the study, and the representation of respondents grouped according to age is satisfactory in all age cohorts (age range 18-98; $\mathrm{M}=50,99, \mathrm{SD}=16,292$ ). More than two thirds of respondents (69.85\%) have an officially assessed highest degree of disability. The survey was voluntary and anonymous. The respondents were not obliged to sign anything, nor give any data that might designate their name to their answers. It was explained to them that the results would be used only as a set of data for statistical analysis on group, and not individual level. ${ }^{20}$

\subsection{Instruments}

For the purpose of this survey, we constructed two sets of questions with a total of five variables by which we attempted to find out the frequency of the experience of discrimination and violence among the respondents. The first question was the following: »Did you, because of your disability, experience some kind of discrimination in the last year? " The second question consisted of

\footnotetext{
${ }^{20}$ For more information about the study see: M. MARINIĆ, S. RIHTAR, Živjeti s invaliditetom u urbanoj sredini. Analiza kvalitete života osoba s invaliditetom u Gradu Zagrebu, Zagreb, Institut društvenih znanosti Ivo Pilar, 2016.
} 
four items answering to the questions whether the respondents had ever experienced some form of violence - physical violence in the family; verbal violence in the family, physical or verbal violence from people outside the family; and violence from medical staff. In all the cases, the respondents needed to choose either the answer "Yes" or the answer "No«.

The affective component of subjective well-being was measured by the adjusted instrument constructed by Fordyce. ${ }^{21}$ The instrument consists of one item by which the respondent is asked to assess his/her usual mood (happiness) on a scale of 11 degrees (0-extremely unhappy, 10-extremely happy). The same scale range was used for measuring life satisfaction, i.e. the cognitive component of subjective well-being (0-extremely dissatisfied, 10 -extremely satisfied).

To explore subjective well-being with regard to specific life domains, we also employed a modified »International Well-being Index - IWI $\aleph^{22}$ in the survey. The original questionnaire consists of the personal and national index, however, in this survey we singled out seven items of the personal well-being index: life standard, health, life achievement, relations with family and friends, feeling of physical safety, acceptance from the community and feeling of safety regarding the future. Both here the participants evaluated their satisfaction with the given aspects of life on a scale of 11 degrees (0-extremely dissatisfied, 10-extremely satisfied). Additionally, we used information on the socio-demographic characteristics of the participants and data on their health status specificities.

\section{Results}

First, we examined the frequency of experience of discrimination due to disability in the past year among various groups of persons with disabilities. ${ }^{23}$ The answers presented in Table II clearly indicate that almost half of respondents had such experience, more precisely $45.07 \%$ of them. It is an exceptionally high proportion, although, in fact, any percentage higher than $" 0$ « is too high a percentage. The situation is especially problematic in the group of deaf and hard of hearing persons, in whom this percentage rises to even $66.34 \%$. It is therefore not surprising that $X^{2}$ test points to a significant difference in the answers of respondents grouped according to the type of their disability $\left(\mathrm{X}^{2}=22.871 ; \mathrm{p}=0.000\right)$.

\footnotetext{
${ }^{21}$ M. W. FORDYCE, A Review of Results on the Happiness Measures: A 60-second Index of Happiness and Mental Health, Social Indicators Research, 20 (1988) 355-381.

${ }^{22}$ R. A. CUMMINS et al., IWI - International Well-Being Index. Developing a National Index of Subjective Wellbeing: The Australian Unity Wellbeing Index, Social Indicators Research, 64 (2003) 2, 159-190.

${ }^{23}$ The percentages of the sample weighted according to size of particular CSOs are presented in: Marinić, Rihtar, Živjeti s..., 65, 115.
} 
Table II. Experience of discrimination due to disability in the past year

\begin{tabular}{|c|c|c|c|c|c|c|}
\hline \multicolumn{2}{|c|}{} & \multicolumn{2}{|c|}{ Physical disability } & \multicolumn{2}{c|}{ Sensory disability } & \multirow{2}{*}{ Total } \\
\cline { 2 - 7 } \multicolumn{2}{|c|}{} & $\begin{array}{c}\text { Easier } \\
\text { movable }\end{array}$ & $\begin{array}{c}\text { Hard of } \\
\text { moving or } \\
\text { immovable }\end{array}$ & $\begin{array}{c}\text { Deaf and } \\
\text { hard of } \\
\text { hearing }\end{array}$ & $\begin{array}{c}\text { Blind and } \\
\text { partially } \\
\text { sighted }\end{array}$ & \\
\hline \multirow{2}{*}{ No } & $\mathrm{N}$ & 163 & 105 & 34 & 60 & 362 \\
\cline { 2 - 7 } & $\%$ & 61.05 & 56.45 & 33.66 & 57.14 & 54.93 \\
\hline \multirow{2}{*}{ Yes } & $\mathrm{N}$ & 104 & 81 & 67 & 45 & 297 \\
\cline { 2 - 7 } & $\%$ & 38.95 & 43.55 & 66.34 & 42.86 & 45.07 \\
\hline \multirow{2}{*}{ Total } & $\mathrm{N}$ & 267 & 186 & 101 & 105 & 659 \\
\cline { 2 - 7 } & $\%$ & 100 & 100 & 100 & 100 & 100 \\
\hline
\end{tabular}

In Table III the answers to the question whether respondents have ever experienced various forms of violence is presented. ${ }^{24}$ It is evident that the most frequent form of experienced violence was physical or verbal violence from persons outside of the family (28.98\%), then verbal violence in the family $(26.02 \%)$, violence from medical staff (12.37\%) and, the least frequent, physical violence in the family (9.53\%). It is indicative once again that deaf and hard of hearing persons experience various forms of violence outside the family circle in the highest percentage, be it physical or verbal violence in general $(40.59 \%)$ or violence coming from medical staff (25.74\%). It was in these two questions that the subgroups' answers to were found to have statistically significant differences.

Table III. Experience of various forms of violence (only »Yes« answers)

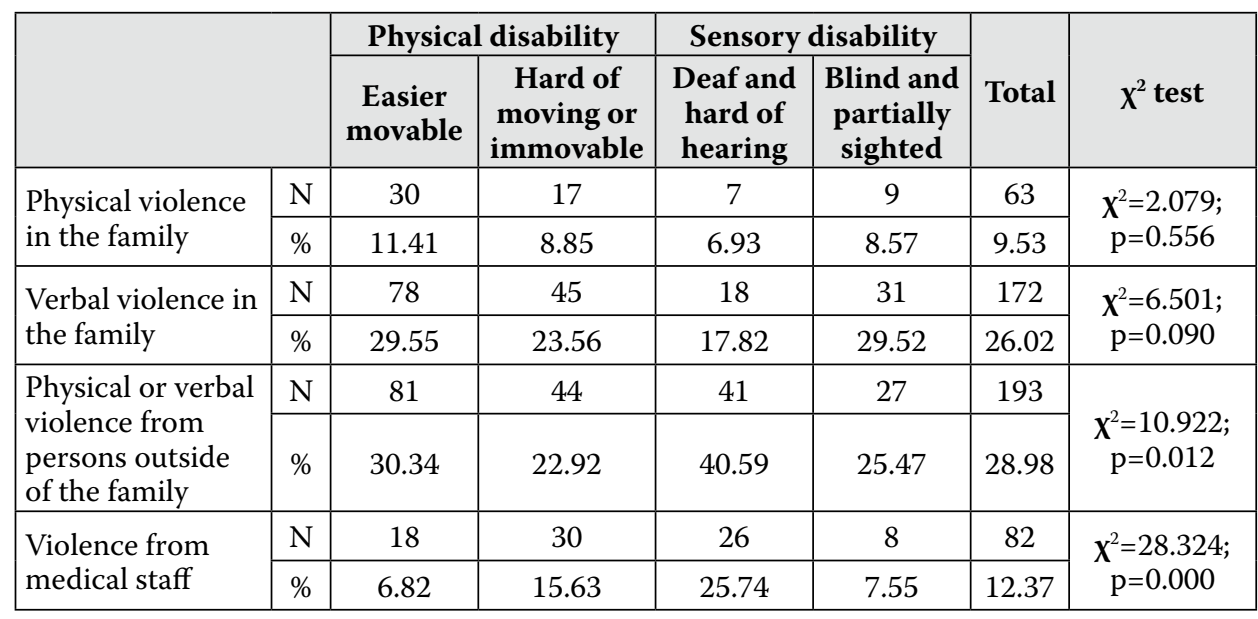

${ }^{24}$ Ibid. 
In the next analysis we attempted to explore what kind of correlation existed between the experience of discrimination in the past year and the level of life satisfaction and feeling of happiness in life. Table IV shows that persons who have had the experience of some form of discrimination in the past year exhibit a lower level of life satisfaction and the feeling of happiness, compared to persons without such experience. T-test analysis proves this clearly.

Table IV. Correlation of discrimination experience with the level of life satisfaction and feeling of happiness in life

\begin{tabular}{|c|c|c|c|c|c|}
\hline & $\begin{array}{c}\text { Experience of } \\
\text { discrimination due } \\
\text { to disability }\end{array}$ & $\mathbf{N}$ & Mean & $\begin{array}{c}\text { Std. } \\
\text { Deviation }\end{array}$ & t-test \\
\hline \multirow{2}{*}{ Life satisfaction } & No & 334 & 6.99 & 2.387 & \multirow{2}{*}{$\mathrm{t}=4.887 ; \mathrm{p}=0.000$} \\
\hline & Yes & 274 & 5.99 & 2.632 & \\
\hline \multirow{2}{*}{$\begin{array}{l}\text { Feeling of } \\
\text { happiness in life }\end{array}$} & No & 337 & 6.97 & 2.366 & \multirow{2}{*}{$\mathrm{t}=3.243 ; \mathrm{p}=0.001$} \\
\hline & Yes & 274 & 6.32 & 2.568 & \\
\hline
\end{tabular}

The same verification was carried out with regard to the experience of violence. However, since here we have 4 variables measuring the frequency of each individual type of violence, in the next analysis we added all four variables into one and called it $»$ Experience of violence in general«. We got a scale with a theoretical range of 4 degrees. The average value of experience of violence on such a scale is 4.77 , where the answer $» 4$ « means complete absence of any of the examined types of violence, and $» 8$ « implies the experience of all these types of violence.

The results shown in Table $\mathrm{V}$ clearly indicate a negative correlation of the experience of violence with the level of life satisfaction and the feeling of happiness.

Table V. Pearson correlation of the experience of violence in general with the level of life satisfaction and feeling of happiness in life

\begin{tabular}{|c|c|c|c|}
\hline & & Life satisfaction & $\begin{array}{c}\text { Feeling of happiness } \\
\text { in life }\end{array}$ \\
\hline \multirow{2}{*}{$\begin{array}{c}\text { Experience of violence } \\
\text { in general }\end{array}$} & $\mathrm{r}$ & $-0.116^{* * *}$ & $-0.146^{* * *}$ \\
\cline { 2 - 4 } & $\mathrm{p}$ & 0.004 & 0.000 \\
\cline { 2 - 4 } & $\mathrm{N}$ & 611 & 613 \\
\hline
\end{tabular}

*** Correlation is significant at the 0.01 level (2-tailed)

In the next analysis, we explored how much the experience of discrimination in the past year is related to the various domains of personal well-being. Employing t-test again, we found a statistically significant correlation of the experience of discrimination due to disability with all domains of personal 
Table VI. Correlation of the experience of discrimination due to disability with various domains of personal well-being

\begin{tabular}{|c|c|c|c|c|c|}
\hline & $\begin{array}{c}\text { Experience of } \\
\text { discrimination due } \\
\text { to disability }\end{array}$ & $\mathbf{N}$ & Mean & $\begin{array}{c}\text { Std. } \\
\text { Deviation }\end{array}$ & t-test \\
\hline \multirow{2}{*}{$\begin{array}{l}\text { Satisfaction with the } \\
\text { living standard }\end{array}$} & No & 334 & 6.32 & 2.633 & \multirow{2}{*}{$\mathrm{t}=7.231 ; \mathrm{p}=0.000$} \\
\hline & Yes & 282 & 4.75 & 2.739 & \\
\hline \multirow{2}{*}{$\begin{array}{l}\text { Satisfaction with the } \\
\text { health }\end{array}$} & No & 339 & 5.05 & 2.900 & \multirow{2}{*}{$\mathrm{t}=2.473 ; \mathrm{p}=0.014$} \\
\hline & Yes & 288 & 4.47 & 2.902 & \\
\hline \multirow{2}{*}{$\begin{array}{l}\text { Satisfaction with the } \\
\text { achievements }\end{array}$} & No & 324 & 6.11 & 2.711 & \multirow{2}{*}{$\mathrm{t}=3.741 ; \mathrm{p}=0.000$} \\
\hline & Yes & 277 & 5.24 & 2.965 & \\
\hline \multirow{2}{*}{$\begin{array}{l}\text { Satisfaction with } \\
\text { interpersonal relations }\end{array}$} & No & 336 & 7.44 & 2.202 & \multirow{2}{*}{$\mathrm{t}=5.227 ; \mathrm{p}=0.000$} \\
\hline & Yes & 285 & 6.44 & 2.577 & \\
\hline \multirow{2}{*}{$\begin{array}{l}\text { Satisfaction with the } \\
\text { feeling of safety }\end{array}$} & No & 334 & 6.74 & 2.720 & \multirow{2}{*}{$t=5.966 ; p=0.000$} \\
\hline & Yes & 283 & 5.36 & 3.003 & \\
\hline \multirow{2}{*}{$\begin{array}{l}\text { Satisfaction with } \\
\text { belonging to the } \\
\text { community }\end{array}$} & No & 333 & 7.37 & 2.545 & \multirow{2}{*}{$t=6.256 ; p=0.000$} \\
\hline & Yes & 276 & 5.971 & 2.971 & \\
\hline \multirow{2}{*}{$\begin{array}{l}\text { Satisfaction with the } \\
\text { feeling of safety in the } \\
\text { future }\end{array}$} & No & 326 & 5.408 & 2.977 & \multirow{2}{*}{$\mathrm{t}=7.333 ; \mathrm{p}=0.000$} \\
\hline & Yes & 275 & 3.662 & 2.824 & \\
\hline
\end{tabular}

well-being. The average value of the level of satisfaction with each of them is visibly higher in persons who did not experience discrimination.

Identical finding was found in the variable of general experience of violence. All domains of personal well-being are significantly correlated with this experience, in the negative direction, i.e. the more frequent the experience of various forms of violence, the lower the level of satisfaction with the analysed life domains.

Table VII. Correlation of the experience of violence in general with various domains of personal well-being

\begin{tabular}{|c|c|c|c|c|c|c|c|c|}
\hline & & 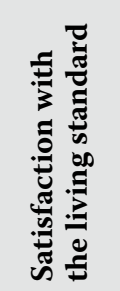 & 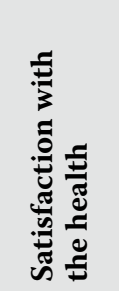 & 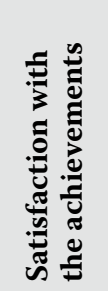 & 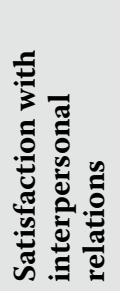 & 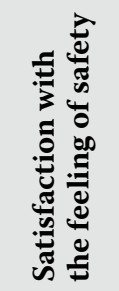 & 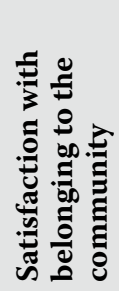 & 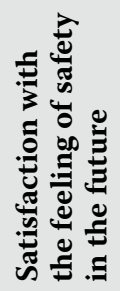 \\
\hline \multirow{3}{*}{$\begin{array}{l}\text { Experience } \\
\text { of violence } \\
\text { in general }\end{array}$} & $\mathrm{r}$ & $-0.188^{* * * *}$ & $-0.109^{* * * *}$ & $-0.104^{*}$ & $-0.131^{* * *}$ & $-0.229^{* * *}$ & $-0.188^{* * * *}$ & $-0.214^{* * * *}$ \\
\hline & $\mathrm{p}$ & 0.000 & 0.006 & 0.010 & 0.001 & 0.000 & 0.000 & 0.000 \\
\hline & $\mathrm{N}$ & 617 & 628 & 603 & 622 & 620 & 610 & 602 \\
\hline
\end{tabular}

** Correlation is significant at the 0.01 level (2-tailed)

* Correlation is significant at the 0.05 level (2-tailed) 
The experience of discrimination and violence was also analysed in the context of several basic socio-demographic characteristics. Statistically significant difference in the average values of answers was not found with regard to the respondents' sex $(t=0,863 ; p=0,389)$, implying that both men and women were equally discriminated. The difference was neither found in the experience of violence in general variable $(t=-1,605 ; \mathrm{p}=0,109)$.

The negative Pearson's correlation clearly shows that in the past year the experience of discrimination due to disability was more often experienced by the respondents of younger age $(\mathrm{r}=-0.189 ; \mathrm{p}=0.000)$ and those with lower income $(\mathrm{r}=-0.172 ; \mathrm{p}=0.000)$. The same was found for the experience of violence in general. Younger respondents report more frequent exposure to some form of the mentioned types of violence, in comparison to the older ones $(\mathrm{r}=-0.081$; $\mathrm{p}=0.041)$. The same was found among those with lower monthly income ( $\mathrm{r}=.-$ $0.110 ; \mathrm{p}=0.006$ ).

Finally, after having ascertained that there is a correlation of the respondents' age and income with their experience of discrimination due to disability and the experience of violence in general, in the next analysis we aimed to find out what their predictive contribution to the explanation of the analysed variables was. We therefore involved the variables of experience of discrimination and experience of violence as dependent, and the variables of age and monthly income per family member as independent variables, i.e. predictors, in the linear regression analysis.

Both age and level of monthly income are a significant predictor of discrimination, however, in the experience of violence variable younger age loses in its importance, i.e. its predictive contribution. If a person is younger and has lower income, he/she will be exposed to discrimination more frequently, whereas regarding the experience of violence, the variable of income actually neutralizes the variable of age, implying that with higher income, the frequency of experienced violence is reduced significantly, regardless of age.

Table VIII. Predictive contribution of sex and age to the variable of experience of discrimination and violence

\begin{tabular}{|c|c|c|c|c|}
\hline & \multicolumn{2}{|c|}{ Discrimination } & \multicolumn{2}{c|}{ Violence } \\
\hline & $\begin{array}{c}\text { Income per } \\
\text { family member }\end{array}$ & Age & $\begin{array}{c}\text { Income per } \\
\text { family member }\end{array}$ & Age \\
\hline Beta & -0.152 & -0.188 & -0.11 & -0.069 \\
\hline $\mathrm{t}$ & -3.836 & -4.755 & -2.701 & -1.692 \\
\hline $\mathrm{p}$ & 0.000 & 0.000 & 0.007 & 0.091 \\
\hline
\end{tabular}




\section{Discussion}

Literature has shown that discrimination towards persons with disabilities happens on the very conceptual level, i.e. in using various inadequate terms for naming this population. ${ }^{25}$ Nevertheless, the problem is not only present on the conceptual level - it exists both on the level of living.

Observing the total sample of persons with disabilities, discrimination was experienced by $45 \%$, while violence by $10-30 \%$ of the respondents, depending on the actual type of violence - which is in line with a study conducted in Croatia in 2009. ${ }^{26}$

The finding suggesting that deaf and hard of hearing persons experience discrimination most often (66\%), and that they also have experience of violence outside their own families (41\%) is very indicative. It is hard to claim with certainty why that is so, however, one of the possible reasons can definitely lie in the fact that the matter we are discussing is a very severe form of disability, which, unlike most other types of disability, is non-visible. The perception of and the relation towards deaf persons, and then the expectations from them, can be significantly more inaccurate, than in the case of persons having visible types of disability. At the same time the inability to establish (a classical model of) communication is very intense, thus reducing significantly the chance of their adequate inclusion in the society, and in this case, resulting in more frequent experiences of discrimination and violence. Moreover, it is possible that deaf persons lack information and education about protection from violence. This is rarely discussed in a form that would be suitable to them, and the written literature on the topic is in fact quite rare.

The results have shown that the experience of discrimination and violence is correlated with lower satisfaction with life in general, and lower feeling of happiness in life. They evidently affect the complete psychophysical structure of a person, and this is confirmed by the finding that both discrimination and violence are significantly correlated with all domains of personal well-being, even with the perception of one's own health status.

Perhaps a little unexpected is the finding that the experience of discrimination and violence is mostly reported by younger age groups. Maybe this is connected with previous research findings suggesting that an unaware person will sometimes discriminate an adult person with disability and treat them »like a child «. ${ }^{27}$ Thus, for example, instead of approaching a person in a wheelchair

\footnotetext{
${ }^{25}$ About it: M. MARINIĆ, Jesu li osobe s invaliditetom »invalidi«? Pitanje konceptualne naravi, ali i potreba izjednačavanja mogućnosti, Društvena istraživanja, 93-94 (2008) 1-2, 199-221, 200s.

${ }^{26}$ E. NAJMAN HIŽMAN, Z. Leutar, Nasilje nad osobama s invaliditetom, Socijalna psihijatrija, 40 (2012) 3, 177-188.

${ }^{27}$ D. PÉREZ-GARÍN et al., Perceived Discrimination and Emotional Reactions in People with Different Types of Disabilities: A Qualitative Approach, The Spanish Journal of Psychology, 21 (2018) e12, 1-11, 4.
} 
directly, this person will approach the disabled person's companion and ask a question concerning the person in a wheelchair. This is especially likely if the person appears young, among other things.

Discrimination and violence are experienced both by female and male respondents equally, and more frequently in families with lower income. The predictive contribution of the age and monthly income variables to the frequency of experience of discrimination and violence is particularly interesting. In the context of discrimination, both predictors have had significant contribution, however, with regard to violence age loses in importance. Only the variable of income remains significant, thus indicating clearly the necessity of assuring decent income and financial stability to every person with disability, because if a person is financially situated, then he/she is less likely to be exposed to violence in all life stages.

\section{Conclusion}

Persons with disabilities are exposed considerably to various forms of violence and discrimination, which then reflects on the level of happiness and satisfaction in life, and generally on their personal well-being. According to the results of this study, but also of numerous previous studies, it seems that structural violence lies at the basis of all types of violence and discrimination, making persons with disabilities vulnerable to additional forms of exploitation, and serving to further isolate them from society. ${ }^{28} \mathrm{~A}$ more active engagement of the authorities and professionals is therefore needed, to implement measures for the protection from discrimination and violence in an adequate way. This type of engagement is necessary to shift the awareness about this problem within the social community to an adequate level and to finally make persons with disabilities accepted as rightful and equal members of society. Additional engagement is also needed, in the sense of education and empowerment of persons with disabilities to reduce as much as possible their exposure to discrimination and violence, to make their coping strategies as appropriate as possible and for their lived experiences to leave as little trace as possible on their lives. Hence, following the authors Nedić at al. ${ }^{29}$ we can conclude that fighting discrimination and violence involves a comprehensive, multidisciplinary approach to the problem, with the aim of developing a society that strives towards balanced and sound interpersonal relationships. This would indeed make the aforementioned and desired phenomenon of »disability paradox« much more present.

\footnotetext{
${ }^{28}$ J. NEILLE, C. PENN, The Interface Between Violence, Disability, and Poverty: Stories from a Developing Country, Journal of Interpersonal Violence, 32 (2017) 18, 2837-2861, 2837s.

${ }^{29}$ M. NEDIĆ, D. MARČINKO, L. POSTRUŽIN, Socijalni, biološki i psihodinamski aspekti nasilja, Socijalna psihijatrija, 44 (2016) 3, 196-207, 196.
} 


\section{Marko Marinić* \\ Povezanost diskriminacije i nasilja sa zadovoljstvom životom, srećom $i$ osobnim blagostanjem u osoba s tjelesnom $i$ osjetilnom invalidnosti \\ Sažetak}

Cilj ovog rada je ispitivanje učestalost doživljaja diskriminacije i nasilja među osobama s različitim vrstama invaliditeta, ispitati povezanost ovih tema s pojedinim sociodemografskim obilježjima, a onda i s razinom sreće i zadovoljstva životom, te utvrditi s kojom su od različitih domena osobnoga blagostanja posebice povezani diskriminacija i nasilje. Provedeno je empirijsko istraživanje među osobama s različitim vrstama invaliditeta $(\mathrm{N}=684) \mathrm{u}$ gradu Zagrebu (Hrvatska). Rezultati pokazuju visok postotak iskustva diskriminacije i nasilja u svim skupinama ispitanika, a posebice među gluhim i nagluhim osobama. I jedna i druga tema u negativnoj su korelaciji s razinom osobne sreće, zadovoljstvom životom te svim domenama osobnoga blagostanja. Pronađena je i povezanost učestalosti ovih iskustava s mlađom životnom dobi, ali i nižim primanjima i lošim ekonomskim statusom. Rezultati upućuju na nužnost multidisciplinarnog i sveobuhvatnog angažmana u smanjivanju diskriminacije i nasilja nad osobama s invaliditetom.

Ključne riječi: diskriminacija, nasilje, osobe s invaliditetom, osobno blagostanje, sreća.

\footnotetext{
* Marko Marinić, PhD, Senior Research Associate at Institute of Social Sciences »Ivo Pilar«; Address: Marulićev trg 19, HR-10000 Zagreb, Croatia; e-mail: marko.marinic@pilar.hr.
} 